\title{
Binding of vitamin A by casein micelles in commercial skim milk
}

\author{
M. S. Mohan, ${ }^{*}$ J. L. Jurat-Fuentes, $†$ and F. Harte ${ }^{* 1}$ \\ ${ }^{*}$ Department of Food Science and Technology, University of Tennessee, Knoxville 37996-4539 \\ †Department of Entomology and Plant Pathology, University of Tennessee, Knoxville 37996-4560
}

\section{ABSTRACT}

Recent studies have shown that reassembled micelles formed by caseinates and purified casein fractions $\left(\alpha_{s^{-}}\right.$ and $\beta$-casein) bind to hydrophobic compounds, including curcumin, docosahexaenoic acid, and vitamin D. However, limited research has been done on the binding of hydrophobic compounds by unmodified casein micelles in skim milk. In the present study, we investigated the ability of casein micelles in commercial skim milk to associate with vitamin A (retinyl palmitate), a fat-soluble vitamin commonly used to fortify milk. Milk protein fractions from different commercially available skim milk samples subjected to different processing treatments, including pasteurized, ultrapasteurized, organic pasteurized, and organic ultrapasteurized milks, were separated by fast protein liquid chromatography. The fractions within each peak were combined and freeze-dried. Sodium dodecyl sulfate-PAGE with silver staining was used to identify the proteins present in each of the fractions. The skim milk samples and fractions were extracted for retinyl palmitate and quantified against a standard using normal phase-HPLC. Retinyl palmitate was found to associate with the fraction of skim milk containing caseins, whereas the other proteins (BSA, $\beta$-lactoglobulin, $\alpha$-lactalbumin) did not show any binding. The retinyl palmitate content in the various samples ranged from 1.59 to $2.48 \mu \mathrm{g}$ of retinyl palmitate per $\mathrm{mL}$ of milk. The casein fractions contained between 14 and $40 \%$ of total retinyl palmitate in the various milks tested. The variation in the retention of vitamin A by caseins was probably explained by differences in the processing of different milk samples, including thermal treatment, the form of vitamin A emulsion used for fortification, and the point of fortification during processing. Unmodified casein micelles have a strong intrinsic affinity toward the binding of vitamin A used to fortify commercially available skim milks.

Key words: vitamin A, milk, casein micelle, size exclusion chromatography

Received May 27, 2012.

Accepted October 28, 2012.

${ }^{1}$ Corresponding author: fede@utk.edu

\section{INTRODUCTION}

Retinyl palmitate (partition coefficient, $\log \mathrm{P}>4.5$ ) is commonly used for vitamin A fortification of commercial whole, $2 \%$, and skim milk. According to the Code of Federal Regulations (21CFR 131.110; http:// www.accessdata.fda.gov/scripts/cdrh/cfdocs/cfcfr/ CFRSearch.cfm? $f r=131.110)$, vitamin A content of fortified milk must be greater than $1.2 \mu \mathrm{g} / \mathrm{mL}(2,000 \mathrm{IU} /$ qt). Vitamin A is normally present in bovine milk at an average amount of $0.81 \mu \mathrm{g} / \mathrm{mL}(1,347 \mathrm{IU} / \mathrm{qt}$; USDAARS, 2011). The per capita milk consumption of 83.9 $\mathrm{L} /$ person provides a very small amount of vitamin A in the diet (IDF, 2007), which makes it essential to fortify milk with vitamin A to help meet the total daily requirement of 700 to $900 \mu \mathrm{g} / \mathrm{d}$ for men and women (Food and Nutrition Board Institute of Medicine, 2001). Vitamin A is added to milk as a mixture of oils and emulsifiers. A typical commercial source for vitamin A and $\mathrm{D}$ fortification in the dairy industry contains corn oil, sorbitan monooelate, polysorbate 80 , retinyl palmitate (vitamin $\mathrm{A}$ ), and cholecalciferol (vitamin $\mathrm{D}_{3}$ ), with $1 \mathrm{~mL}$ containing 200,000 IU of vitamin A and 40,000 IU of vitamin $\mathrm{D}_{3}$. Although the addition of oils and emulsifiers makes it possible for vitamin $\mathrm{A}$ to be dispersed in the continuous serum phase of milk, milk proteins are also known to bind hydrophobic compounds.

About $80 \%$ of the total $3.6 \%$ of proteins in milk are caseins. Caseins in milk exist as supramolecular structures called casein micelles, ranging in diameter from 50 to $500 \mathrm{~nm}$, with an average of $120 \mathrm{~nm}$ (Fox and Brodkorb, 2008). The structure of the casein micelles has been widely studied and disputed (Dalgleish, 2011). The consensus is that the structure of the casein micelles is mainly stabilized by hydrophobic and ionic interactions (Horne, 1998; Holt et al., 2003). The latest studies confirm the presence of several cavities $(\sim 20$ to $30 \mathrm{~nm}$ in diameter) and channels ( $>5 \mathrm{~nm}$ in diameter) within the casein micelle structure (Trejo et al., 2011). Reassembled casein micelles produced by various methods were shown to entrap hydrophobic probes such as triclosan, vitamin $\mathrm{D}_{2}$, and docosahexaenoic acid (DHA; Semo et al., 2003; Roach et al., 2009; Zimet et al., 2011). Micelles formed from $\beta$-caseins act as a drug delivery system, for example, by entrapping a hydro- 
phobic anticancer drug, mitoxantrone, within it (Shapira et al., 2010). Milk proteins, especially caseins, were shown to bind to green tea flavonoids by their decrease in hydrophobicity upon binding to these hydrophobic polyphenols (Yuksel et al., 2010). Another study evaluated the ability of native caseins to form micelles and complex with curcumin as a potential drug nanocarrier against cancer cells (Sahu et al., 2008). Reassembled $\alpha_{S 1}$-casein micelles also bind with curcumin (Sneharani et al., 2009). All of these studies show the ability of reassembled casein micelles or individual caseins to bind hydrophobic molecules. This ability of casein micelles to bind has been associated with the existence of hydrophobic forces, cavities, and channels within the micelle structure.

Milk whey proteins also exhibit nonspecific affinity to bind hydrophobic molecules. $\beta$-Lactoglobulin has been shown to bind to vitamin $\mathrm{D}_{3}$ (Forrest et al., 2005), retinol (Dufour and Haertlé, 1991), DHA (Zimet and Livney, 2009), and polyphenolic compounds such as resveratol from grapes (Hemar et al., 2011) and epigallocatechin gallate from green tea (Kanakis et al., 2011). $\alpha$-Lactalbumin has been shown to complex with retinol and palmitic acid (Puyol et al., 1991); and BSA can form a water-soluble complex with retinol, possibly acting as an in vivo carrier of excess free retinol introduced into the circulation (Futterman and Heller, 1972). Bovine serum albumin is also known to bind to ascorbates, which are precursors of vitamin C (Oelrichs et al., 1984).

In the present study, we investigated the ability of casein micelles and whey proteins to entrap vitamin A without altering the natural conditions in which they are present in commercially available, heat-treated skim milk samples. Heating induces conformational changes in proteins, which affect their binding to hydrophobic molecules (Kulmyrzaev et al., 2005). Whey proteins denature when milk is processed to temperatures above $60^{\circ} \mathrm{C}$ and form casein-whey protein complexes (Donato and Guyomarc'h, 2009). The objective of this study was to investigate the ability of the various protein fractions in fortified commercial skim milks to bind retinyl palmitate. The thermal treatments of these skim milks may promote conformational changes that affect the binding of proteins. Our aim was to study the ability of fractions of milk proteins in commercially available skim milk samples to bind the vitamin A fortified in them.

\section{MATERIALS AND METHODS}

\section{Milk Samples and Protein-Free Serum}

Four commercially available skim milks fortified with vitamin A (as retinyl palmitate) were studied. Skim milk contains less than $0.5 \%$ fat (21CFR 131.110; http:/ / www. accessdata.fda.gov/scripts/cdrh/cfdocs/cfcfr/CFR Search.cfm?fr=131.110). The skim milk samples were chosen based on the following processing criteria: pasteurized, organic pasteurized, ultrapasteurized, and organic ultrapasteurized. Because no information was available on the specific processing conditions for each milk, the obtained results were not considered representative of the universe of a given type of milk (e.g., pasteurized organic). To avoid inaccurate conclusions related to processing or milk origin, the samples are named milk-1, milk-2, milk-3, and milk-4. Protein-free serum was prepared from pasteurized skim milk using a cellulose tangential-flow ultrafiltration system (PLBC Prep scale TFF Cartridge, Millipore, Billerica, MA), with a molecular weight cutoff of $3 \mathrm{kDa}$, preserved with $0.07 \%$ (wt $/ \mathrm{vol}$ ) sodium azide, and stored at $4^{\circ} \mathrm{C}$.

\section{Size-Exclusion Chromatography}

Skim milk samples $(2 \mathrm{~mL})$ were separated into the different protein fractions by using a size-exclusion chromatography (SEC) column (HiLoad 16/60 Superdex 200 prep grade, GE Life Sciences, GE Health Care, Piscataway, NJ) connected to a fast protein liquid chromatography (FPLC) unit (AKTA, GE Life Sciences). Ice-cold protein-free serum was used as the mobile phase. Separation was achieved using a flow rate of $1.0 \mathrm{~mL} / \mathrm{min}$, and $1-\mathrm{mL}$ fractions were collected using an automatic fraction collector (Frac-950, GE Life Sciences) after 0.3 column volumes for a total elution volume of 1.5 column volumes $(\sim 180 \mathrm{~mL})$. Peaks were detected using UV light at $280 \mathrm{~nm}$. Collected fractions within the same peak (protein milk fractions) were pooled and freeze-dried.

\section{HPLC}

Extraction of vitamin A from skim milk samples was done by liquid-liquid extraction, as detailed in AOAC method 2002.06 (AOAC International, 2006). Briefly, 2 -mL milk samples were transferred into $30-\mathrm{mL}$ centrifuge tubes to which $5 \mathrm{~mL}$ of absolute ethanol was added. The tubes were mixed by vortexing for $30 \mathrm{~s}$ and left to stand for $5 \mathrm{~min}$. Then, $5 \mathrm{~mL}$ of hexane was added and the samples were subjected to 3 cycles of vortexing (30 s) and standing (2 min). In the final step, $3 \mathrm{~mL}$ of deionized water was added to samples, mixed by vortexing for $5 \mathrm{~s}$, and centrifuged for $10 \mathrm{~min}$ at $633 \times g$ (RC-5B centrifuge, SH-3000 rotor, Sorvall, Newport Pagnell, UK). The top hexane layer in the tubes was then transferred to amber HPLC vials and loaded to the HPLC system equipped with a diode array detector (1200 series, Agilent Technologies, Santa 


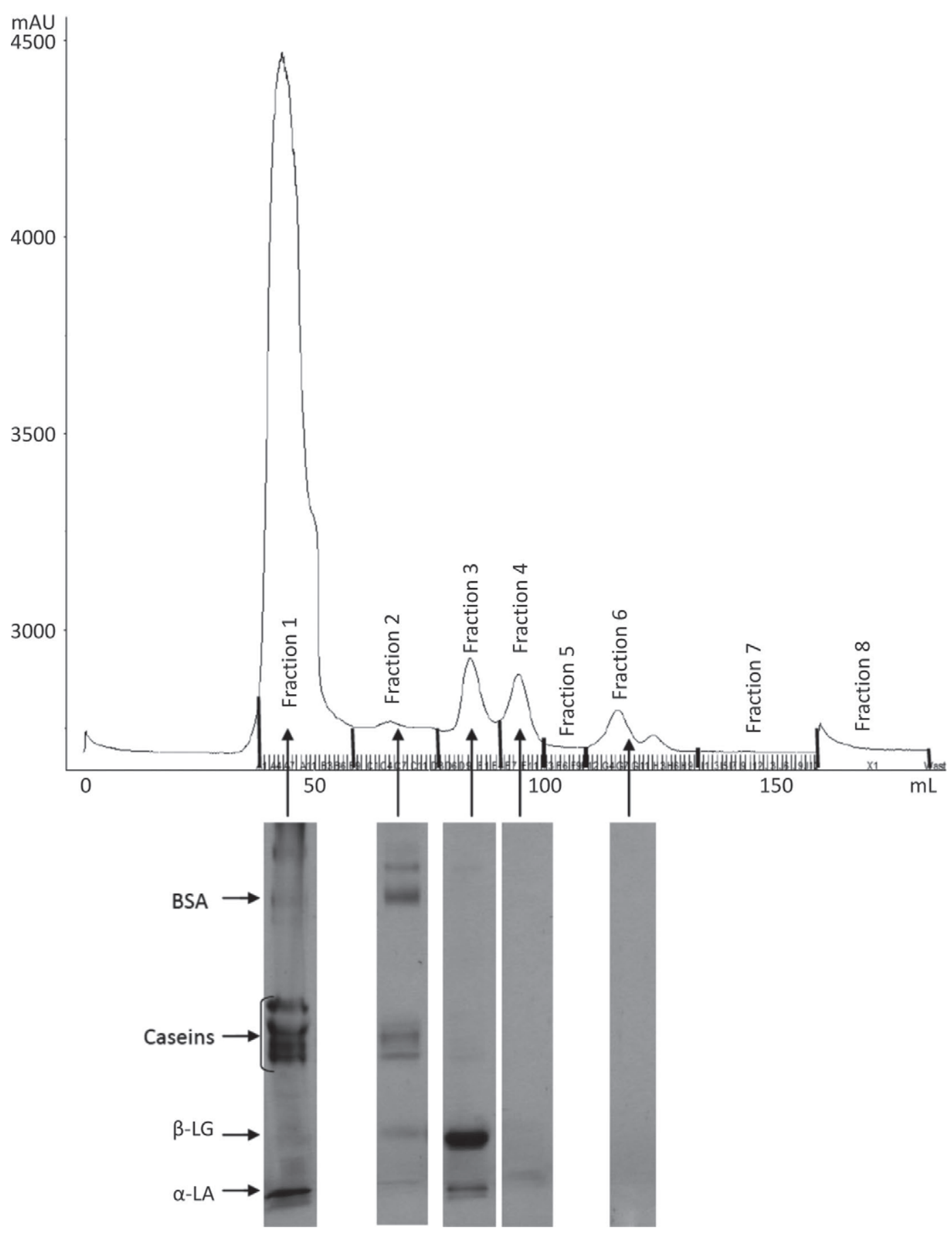

Figure 1. Fast protein liquid chromatograph (FPLC) of sample milk1 and SDS-PAGE gel fragments indicating the proteins present in each peak of the chromatograph.

Clara, CA). The HPLC was performed using a normalphase silica $4.6-\times 250-\mathrm{mm}$ column (Zorbax Rx-SIL, Agilent Technologies) set at $23^{\circ} \mathrm{C}$. The mobile phase was conditioned hexane prepared from $99.85 \%$ (vol/ vol) of wet hexane $(500 \mathrm{~mL}$ of hexane conditioned with $25 \mathrm{~mL}$ of distilled water overnight) and $0.15 \%$ (vol/vol) of isopropanol, and was pumped at flow rate of $1 \mathrm{~mL} /$ min. The automatic injection system injected $100 \mu \mathrm{L}$ of sample into the system and the vitamin A (retinyl palmitate) peak was detected between 2.5 and 3.0 min of retention by absorbance at $325 \mathrm{~nm}$. The vitamin A content was calculated using a standard curve constructed using a retinyl palmitate standard (\#R1512, Sigma-Aldrich, St. Louis, MO) and expressed in micro- 


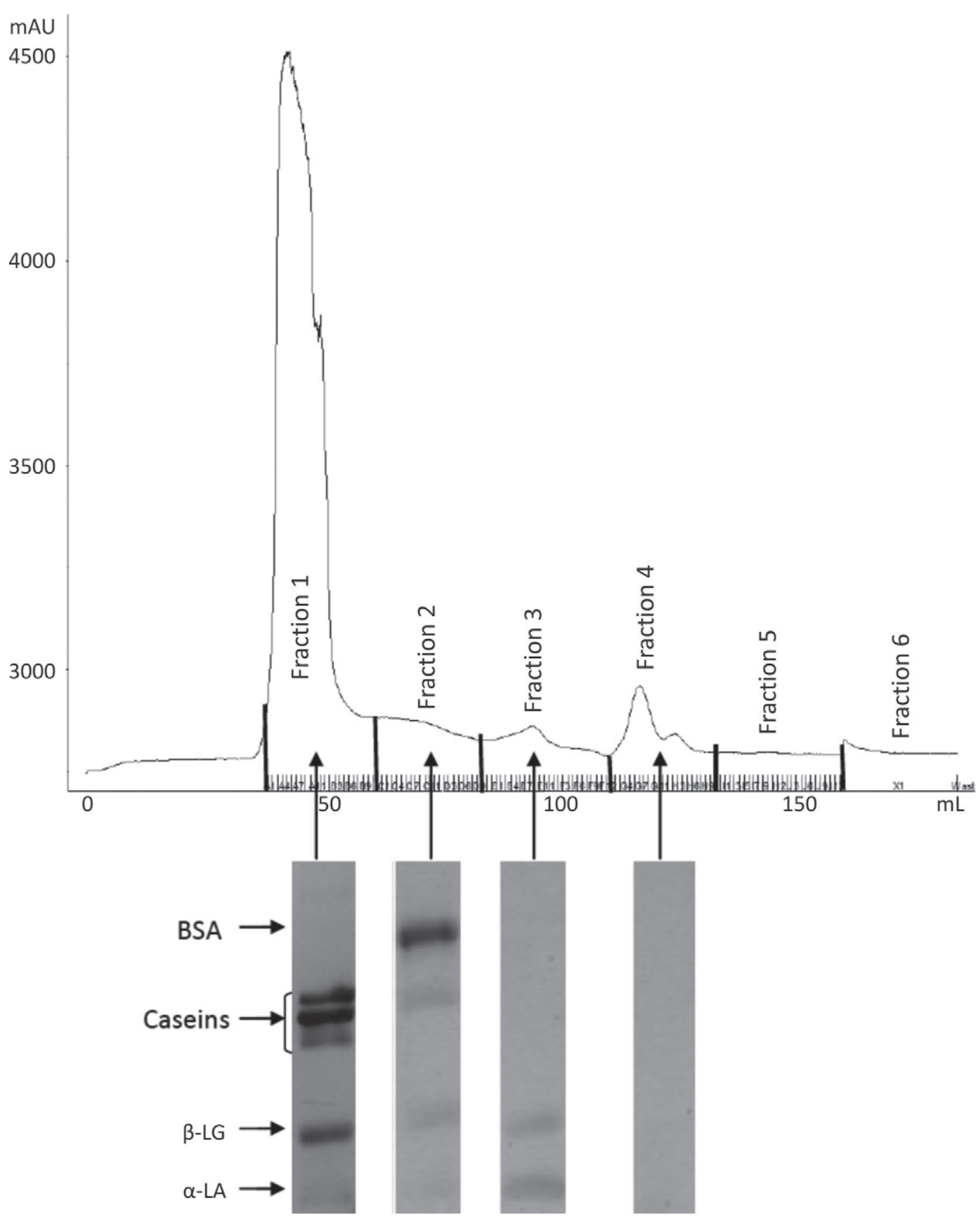

Figure 2. Fast protein liquid chromatograph (FPLC) of sample milk2 and SDS-PAGE gel fragments indicating the proteins present in each peak of the chromatograph.

grams per milliliter of milk. The freeze-dried fractions were diluted with $1 \mathrm{~mL}$ of distilled water and extracted using the method described above.

\section{SDS-PAGE}

The solid and liquid phases (obtained after removing the hexane layer for vitamin A extraction) from each fraction of the milk samples were mixed thoroughly, and SDS-PAGE was performed following a method adapted from Laemmli (1970). From this mixture, 150 $\mu \mathrm{L}$ was mixed with loading buffer $[0.5 \mathrm{M}$ Tris- $\mathrm{HCl}, \mathrm{pH}$ 6.8, glycerol, $10 \%$ (wt/vol) SDS, $\beta$-mercaptoethanol, $0.5 \%$ (wt/vol) bromophenol blue in water; Fisher Scientific, Fair Lawn, NJ]. These samples were heated in a water bath at $95^{\circ} \mathrm{C}$ for 5 min, and then loaded on an 


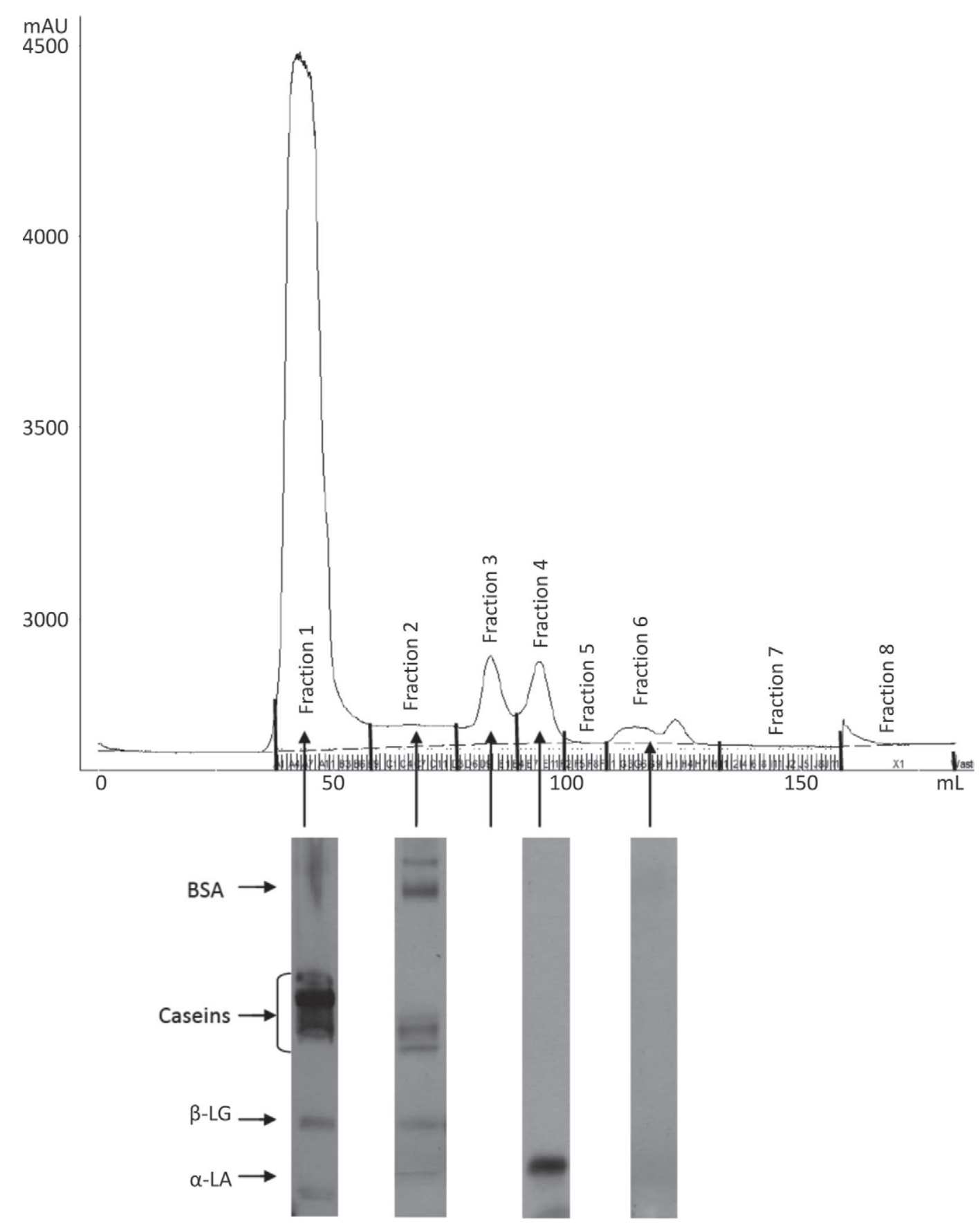

Figure 3. Fast protein liquid chromatograph (FPLC) of sample milk3 and SDS-PAGE gel fragments indicating the proteins present in each peak of the chromatograph. The gel fragment for fraction 3 is missing.

electrophoresis gel (12\% Tris-HCl, 12 wells, Ready Gel, Bio-Rad, Hercules, CA) along with $10 \mu \mathrm{L}$ of prestained standard (Kaleidoscope, \#161-0324, Bio-Rad). The gel was subjected to an electric current of $-200 \mathrm{~V}$ for 38 min and then silver stained. After sufficient stain was observed, staining was stopped and the gel dried (GelAir Drying System, Bio-Rad).

\section{Statistical Analysis}

Statistical analysis of data was done using the MIXED procedure of SAS (version 9.3, 2003; SAS Institute Inc., Cary, NC) in a completely randomized design. Analysis of variance was used to calculate the mean and standard error for retinyl palmitate concentration 


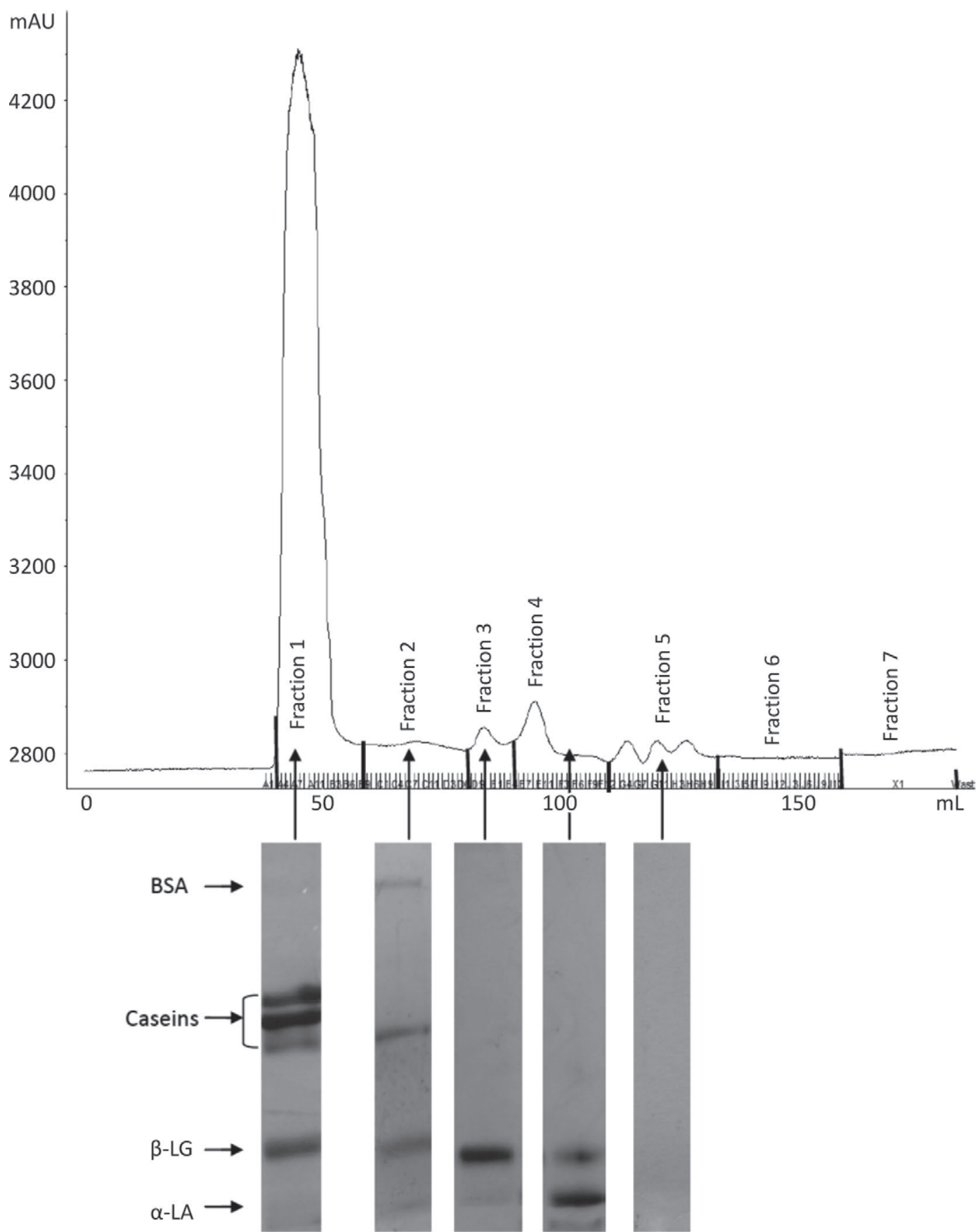

Figure 4. Fast protein liquid chromatograph (FPLC) of sample milk4 and SDS-PAGE gel fragments indicating the proteins present in each peak of the chromatograph.

in samples of skim milk and skim milk casein fractions. Two replicate samples of commercially available skim milk with the same processing criteria from different brands were chosen for analysis. Duplicate samples from different containers of skim milk from the same manufacturer and batch, having undergone the same processing conditions, were studied for each replicate sample of milk.

\section{RESULTS AND DISCUSSION}

\section{FPLC and SDS-PAGE}

The FPLC chromatograms indicated the presence of 4 different fractions of proteins in the skim milk samples based on their size or molecular weight (Figures 1, 2, 3, and 4). To identify the proteins, the fractions in each 
Table 1. Percentage peak areas $^{1}$ within total peak area of all proteins (fractions 1 to 4 ) in the FPLC chromatographs of different skim milk samples

\begin{tabular}{|c|c|c|c|c|c|c|c|c|}
\hline \multirow[b]{2}{*}{ Sample $^{2}$} & \multicolumn{2}{|c|}{ Fraction 1} & \multicolumn{2}{|c|}{ Fraction 2} & \multicolumn{2}{|c|}{ Fraction 3} & \multicolumn{2}{|c|}{ Fraction 4} \\
\hline & Mean & $\mathrm{SE}$ & Mean & $\mathrm{SE}$ & Mean & $\mathrm{SE}$ & Mean & $\mathrm{SE}$ \\
\hline Milk1 & 81.1 & 1.0 & 6.2 & 0.82 & $6.9^{\mathrm{a}}$ & 0.23 & 5.7 & 0.40 \\
\hline Milk-2 & 86.3 & & 9.1 & & $3.7^{\mathrm{b}}$ & & - & \\
\hline Milk-3 & 82.4 & & 4.9 & & $6.6^{\mathrm{a}}$ & & 6.0 & \\
\hline Milk-4 & 88.6 & & 3.5 & & $2.6^{\mathrm{b}}$ & & 5.4 & \\
\hline
\end{tabular}

$\overline{\mathrm{a}, \mathrm{b}}$ Values within a column followed by a different superscript differ $(P<0.01)$.

${ }^{1}$ Peak area represented as percentage of total peak area of the protein peaks in that skim milk sample. Mean of duplicates for each skim milk.

peak were pooled, freeze-dried, and subjected to SDSPAGE. The SDS-PAGE results indicated the presence of mainly caseins in peak 1 (fraction 1 ), BSA in peak 2 (fraction 2), $\beta-\mathrm{LG}$ in peak 3 (fraction 3 ), and $\alpha-\mathrm{LA}$ in peak 4 (fraction 4 ), although each peak contained some fractions of other proteins as well (Figures 1 to 4). Similar results were observed in previous studies conducted in our laboratory (Trejo, 2009). Peak 5, with a shoulder, indicated the presence of another proteinaceous fraction; however, the SDS-PAGE did not show any proteins in this peak. Other studies, such as that conducted by Guyomarc'h et al. (2003), have observed similar nonprotein fractions with absorbance detection at $280 \mathrm{~nm}$ for SEC. The FPLC chromatograms of milk-2 sample showed $\beta$-LG and $\alpha$-LA whey proteins eluting in the same peak. This was accompanied by the absence of peak 4 for this skim milk sample in Table 1. This could be a result of the association of whey proteins with casein micelles because of the specific thermal treatment in milk-2 (ultrapasteurized). A number of studies show results that support the unfolding, aggregation, and polymerization of $\beta-\mathrm{LG}$ and $\alpha-\mathrm{LA}$ whey proteins in milk following treatment at high temperature (Singh, 1995; Oldfield et al., 1998). Aside from the temperature, differences in the heating method, the time required to reach the desired temperature, and the actual retention time also cause such variations (Oldfield et al., 1998). Fraction 1, containing mostly caseins, has been referred to as the casein fraction of skim milk. The presence of small fractions of whey proteins along with the casein fraction in peak 1 resulted from the heat treatment to which the skim milk samples were subjected, as reported in other studies (Singh, 1995; Anema and Li, 2003). Peak 2 contained fractions of $\beta$-casein, $\kappa$-casein, and whey proteins other than BSA. The presence of these fractions indicates the formation of soluble aggregates upon exposure to the heat treatments in the skim milk samples (Dalgleish et al., 1997). Table 1 indicates that peak 1 in all milks, containing mainly caseins, accounted for 81 to $89 \%$ of the total peak area for all proteins in the milk. We observed no significant differences in the percentage peak area of peaks 1 and 2 among all milk samples. Hence, despite the slight variations in peak 3 , all milk samples had similar protein fractions in all peaks, as observed by SEC. Although the absorbance peaks in the FPLC chromatograph depend on the extinction coefficients of each protein constituting the peak, Table 1 shows the effect of different processing conditions on the protein make-up of each FPLC peak.

\section{Vitamin A in Skim Milk and Its Fractions}

The retinyl palmitate content of skim milk samples was quantified by using HPLC (Table 2). The retinyl palmitate content was highest in milk-1 $(2.48 \pm 0.02$

Table 2. Retinyl palmitate content in skim milks and in casein of skim milks and retention of retinyl palmitate in casein as a percentage of the total content in each skim milk sample

\begin{tabular}{|c|c|c|c|c|c|c|}
\hline \multirow[b]{3}{*}{ Sample } & \multicolumn{4}{|c|}{ Retinyl palmitate content ${ }^{2}(\mu \mathrm{g} / \mathrm{mL}$ of milk) } & & \\
\hline & \multicolumn{2}{|c|}{ Skim milk } & \multicolumn{2}{|c|}{ Casein } & \multicolumn{2}{|c|}{$\begin{array}{l}\text { Retention of retinyl } \\
\text { palmitate in } \operatorname{casein}^{1}(\%)\end{array}$} \\
\hline & Mean & $\mathrm{SE}$ & Mean & SE & Mean & $\mathrm{SE}$ \\
\hline Milk-1 & $2.48^{\mathrm{a}}$ & 0.02 & $0.918^{\mathrm{a}}$ & 0.03 & $37.0^{\mathrm{a}}$ & 2.13 \\
\hline Milk-2 & $1.59^{\mathrm{d}}$ & & $0.222^{\mathrm{d}}$ & & $14.0^{\mathrm{c}}$ & \\
\hline Milk-3 & $2.23^{\mathrm{b}}$ & & $0.555^{\mathrm{c}}$ & & $24.9^{\mathrm{b}}$ & \\
\hline Milk-4 & $1.82^{\mathrm{c}}$ & & $0.734^{\mathrm{b}}$ & & $40.4^{\mathrm{a}}$ & \\
\hline
\end{tabular}


$\mu \mathrm{g} / \mathrm{mL}$ of milk) and lowest in milk-2 $(1.59 \pm 0.02 \mu \mathrm{g} /$ $\mathrm{mL}$ of milk). The retinyl palmitate contents of milk-3 and milk- 4 were $2.23 \pm 0.02$ and $1.82 \pm 0.02 \mu \mathrm{g} / \mathrm{mL}$ of milk, respectively. These differences might be due to the type and amount of vitamin A added and the processing methods used for incorporation by the different companies. Earlier studies have shown that the amount of vitamin A fortified varies widely in fluid milk available on the market (Murphy et al., 2001).

Retinyl palmitate content was quantified in the different freeze-dried fractions (fractions 1 to 8) obtained from FPLC of skim milk samples. Vitamin A was detected only in the casein fraction of the skim milk samples. The eluate obtained before the elution of peaks contained no retinyl palmitate. Caseins in milk have been reported to be associated with other hydrophobic probes; for example, vitamin $\mathrm{D}_{2}$, DHA, curcumin, and green tea flavonoids (Semo et al., 2003; Sahu et al., 2008; Yuksel et al., 2010; Zimet et al., 2011). Cavities, channels, and hydrophobic forces within casein micelles are associated with its ability to bind small hydrophobic probes (Trejo et al., 2011). The retinyl palmitate contents of the casein fraction were $0.915,0.222,0.555$, and $0.734( \pm 0.03) \mu \mathrm{g} / \mathrm{mL}$ of milk- 1 , milk- 2 , milk- 3 , and milk-4, respectively (Table 2). Earlier studies on the structure of casein micelles and their binding properties indicate a high likelihood of retinyl palmitate being trapped within the casein micelles. Some studies have shown that small fractions of fat and phospholipids, which can bind hydrophobic compounds, are found along with casein micelles after SEC (Corredig and Dalgleish, 1998). The milk fat globule membrane (which consists mainly of phospholipids) has also been shown to associate with whey proteins (Corredig and Dalgleish, 1996). Another possibility is the formation of small emulsion droplets of retinyl palmitate eluting with casein micelles in the first peak. This was considered unlikely because the various vitamin A droplets, and phospholipids or fat droplets containing vitamin A, would have eluted with other milk proteins throughout the chromatograph, whereas our results showed measurable vitamin A only in the peak corresponding to casein micelles. Further studies need to be conducted to confirm the association of retinyl palmitate with casein micelles.

Although the casein fraction retained an average of $29 \%$ and a maximum of $40 \%$ of the total retinyl palmitate in the skim milk, the percentage of total vitamin A retained in the casein varied among the commercial milks used (Table 2). The highest amount of retinyl palmitate was retained in the casein of milk-4 (40.4 $\pm 2.13 \%)$ and milk-1 $(37.0 \pm 2.13 \%)$, which were not significantly different. The lowest amount of retinyl palmitate was retained in the casein of milk-2 (14.0 \pm
$2.13 \%$ ). Milk-3 retained $24.9 \pm 2.13 \%$ of retinyl palmitate compared with the total amount in the skim milk. These results account for only part of the retinyl palmitate - that retained in the casein fraction. In a study conducted by Semo et al. (2003), the total retention of vitamin $\mathrm{D}_{2}$ in casein and the serum phase was up to $85 \%$ of the amount originally added. The reason for this incomplete retention in our study is not yet known.

Several factors may explain the variation in the retention of retinyl palmitate in the casein of different skim milks, including the type of vitamin A emulsion added to the milk. Studies have also shown that combinations of different process parameters, such as temperature, $\mathrm{pH}$, and pressure, on skim milk affect the binding properties of casein micelles (Orlien et al., 2010). Heating milk alters the ability of casein micelles to bind to curcumin (Yazdi and Corredig, 2012). In the present study, however, the effect of processing of the milks, including thermal processing and homogenization, on the retinyl palmitate content is not known. Earlier surveys have shown that variations also exist in the processing points at which retinyl palmitate is added during the processing of milk (Hicks et al., 1996).

\section{CONCLUSIONS}

Casein micelles in fortified commercial skim milk were found to act as carriers of up to $40 \%$ of the total vitamin A added to milk. Earlier studies indicated the ability of reassembled casein micelles to act as nanocarriers, nanovehicles, or microencapsulates, and the present study further shows the ability of unmodified casein micelles to bind hydrophobic molecules such as vitamin $\mathrm{A}$.

\section{ACKNOWLEDGMENTS}

This research was supported by the Dairy Research Institute (Rosemont, IL), the University of Tennessee Institute of Agriculture (Knoxville), and the National Institutes of Health (Bethesda, MD; project 1R21HD065170-01A1).

\section{REFERENCES}

Anema, S. G., and Y. M. Li. 2003. Association of denatured whey proteins with casein micelles in heated reconstituted skim milk and its effect on casein micelle size. J. Dairy Res. 70:73-83.

AOAC International. 2006. Official Methods of Analysis. 18th ed. AOAC International, Gaithersburg, MD.

Corredig, M., and D. G. Dalgleish. 1996. Effect of different heat treatments on the strong binding interactions between whey proteins and milk fat globules in whole milk. J. Dairy Res. 63:441-449.

Corredig, M., and D. G. Dalgleish. 1998. Effect of heating of cream on the properties of milk fat globule membrane isolates. J. Agric. Food Chem. 46:2533-2540. 
Dalgleish, D. G. 2011. On the structural models of bovine casein micelles-Review and possible improvements. Soft Matter 7:22652272 .

Dalgleish, D. G., V. Senaratne, and S. Francois. 1997. Interactions between $\alpha$-lactalbumin and $\beta$-lactoglobulin in the early stages of heat denaturation. J. Agric. Food Chem. 45:3459-3464.

Donato, L., and F. Guyomarc'h. 2009. Formation and properties of the whey protein $/ \kappa$-casein complexes in heated skim milk-A review. J. Dairy Sci. Technol. 89:3-29.

Dufour, E., and T. Haertlé. 1991. Binding of retinoids and $\beta$-carotene to $\beta$-lactoglobulin. Influence of protein modifications. Biochim. Biophys. Acta 1079:316-320.

Food and Nutrition Board of the Institute of Medicine. 2001. Dietary Reference Intakes for Vitamin A, Vitamin K, Arsenic, Boron, Chromium, Copper, Iodine, Iron, Manganese, Molybdenum, Nickel, Silicon, Vanadium, and Zinc. National Academies Press, Washington, DC.

Forrest, S. A., R. Y. Yada, and D. Rousseau. 2005. Interactions of vitamin $\mathrm{D}_{3}$ with bovine $\beta$-lactoglobulin $\mathrm{A}$ and $\beta$-casein. J. Agric. Food Chem. 53:8003-8009.

Fox, P. F., and A. Brodkorb. 2008. The casein micelle: Historical aspects, current concepts and significance. Int. Dairy J. 18:677-684.

Futterman, S., and J. Heller. 1972. The enhancement of fluorescence and the decreased susceptibility to enzymatic oxidation of retinol complexed with bovine serum albumin, $\beta$-lactoglobulin, and the retinol-binding protein of human plasma. J. Biol. Chem. 247:5168-5172.

Guyomarc'h, F., A. J. R. Law, and D. G. Dalgleish. 2003. Formation of soluble and micelle-bound protein aggregates in heated milk. J. Agric. Food Chem. 51:4652-4660.

Hemar, Y., M. Gerbeaud, C. M. Oliver, and M. A. Augustin. 2011. Investigation into the interaction between resveratrol and whey proteins using fluorescence spectroscopy. Int. J. Food Sci. Technol. 46:2137-2144.

Hicks, T., A. P. Hansen, and J. E. Rushing. 1996. Procedures used by North Carolina dairies for vitamins A and D fortification of milk. J. Dairy Sci. 79:329-333.

Holt, C., C. G. de Kruif, R. Tuinier, and P. A. Timmins. 2003. Substructure of bovine casein micelles by small-angle X-ray and neutron scattering. Colloids Surf. A Physicochem. Eng. Asp. 213:275-284

Horne, D. S. 1998. Casein interactions: Casting light on the black boxes, the structure in dairy products. Int. Dairy J. 8:171-177.

IDF (International Dairy Federation). 2007. The world dairy situation 2007. Bull. Int. Dairy Fed. 423:76-84.

Kanakis, C. D., I. Hasni, P. Bourassa, P. A. Tarantilis, M. G. Polissiou, and H.-A. Tajmir-Riahi. 2011. Milk $\beta$-lactoglobulin complexes with tea polyphenols. Food Chem. 127:1046-1055.

Kulmyrzaev, A. A., D. Levieux, and E. Dufour. 2005. Front-face fluorescence spectroscopy allows the characterization of mild heat treatments applied to milk. relations with the denaturation of milk proteins. J. Agric. Food Chem. 53:502-507.

Laemmli, U. K. 1970. Cleavage of structural proteins during the assembly of the head of bacteriophage T.4. Nature 227:680-685.

Murphy, S. C., L. J. Whited, L. C. Rosenberry, B. H. Hammond, D. K. Bandler, and K. J. Boor. 2001. Fluid milk vitamin fortification compliance in New York State. J. Dairy Sci. 84:2813-2820.
Oelrichs, B. A., C. C. Kratzing, J. D. Kelly, and D. J. Winzor. 1984 The binding of ascorbate to bovine serum albumin. Int. J. Vitam. Nutr. Res. 54:61-64.

Oldfield, D. J., H. Singh, M. W. Taylor, and K. N. Pearce. 1998. Kinetics of denaturation and aggregation of whey proteins in skim milk heated in an ultra-high temperature (UHT) pilot plant. Int. Dairy J. 8:311-318.

Orlien, V., L. Boserup, and K. Olsen. 2010. Casein micelle dissociation in skim milk during high-pressure treatment: Effects of pressure, $\mathrm{pH}$, and temperature. J. Dairy Sci. 93:12-18.

Puyol, P., M. D. Perez, J. M. Ena, and M. Calvo. 1991. Interaction of $\beta$-lactoglobulin and other bovine and human whey proteins with retinol and fatty acids. Agric. Biol. Chem. 10:2515-2520.

Roach, A., J. Dunlap, and F. Harte. 2009. Association of triclosan to casein proteins through solvent-mediated high-pressure homogenization. J. Food Sci. 74:N23-N29.

Sahu, A., N. Kasoju, and U. Bora. 2008. Fluorescence study of the curcumin-casein micelle complexation and its application as a drug nanocarrier to cancer cells. Biomacromolecules 9:2905-2912.

Semo, E. E. Kesselman, D. Danino, and Y. D. Livney. 2003. Casein micelle as a natural nano-capsular vehicle for nutraceuticals. Food Hydrocoll. 21:936-942.

Shapira, A., Y. G. Assaraf, and Y. D. Livney. 2010. Beta-casein nanovehicles for oral delivery of chemotherapeutic drugs. Nanomedicine 6:119-126.

Singh, H. 1995. Heat-induced changes in casein, including interactions with whey proteins. Pages 86-104 in Heat-Induced Changes in Milk. 2nd ed. Special Issue No. 9501. P. F. Fox, ed. International Dairy Federation, Brussels, Belgium.

Sneharani, A. H., S. A. Singh, and A. G. Appu Rao. 2009. Interaction of $\alpha_{\mathrm{S}_{1}}$-casein with curcumin and its biological implications. J. Agric. Food Chem. 57:10386-10391.

Trejo, R. 2009. Casein micelles from bovine milk: Ethanol induced changes in hydrophobicity and interaction with native whey proteins. MS Thesis. University of Tennessee, Knoxville.

Trejo, R., T. Dokland, J. Jurat-Fuentes, and F. Harte. 2011. Cryotransmission electron tomography of native casein micelles from bovine milk. J. Dairy Sci. 94:5770-5775.

USDA-ARS. 2011. National nutrient database for standard reference. Release 24. Accessed Mar. 2012. http://www.ars.usda.gov/ nutrientdata.

Yazdi, S. R., and M. Corredig. 2012. Heating of milk alters the binding of curcumin to casein micelles. A fluorescence spectroscopy study. Food Chem. 132:1143-1149. http://dx.doi.org/10.1016/j. foodchem.2011.11.019.

Yuksel, Z., E. Avci, and Y. K. Erdem. 2010. Characterization of binding interactions between green tea flavanoids and milk proteins. Food Chem. 121:450-456.

Zimet, P., and Y. D. Livney. 2009. Beta-lactoglobulin and its nanocomplexes with pectin as vehicles for $\omega-3$ polyunsaturated fatty acids. Food Hydrocoll. 23:1120-1126.

Zimet, P., D. Rosenberg, and Y. D. Livney. 2011. Re-assembled casein micelles and casein nanoparticles as nano-vehicles for $\omega-3$ polyunsaturated fatty acids. Food Hydrocoll. 25:1270-1276. 